\title{
Choroidal folds
}

\section{Dobras de coroide}

Ricardo Luz Leitão Guerra', Igor Sandes Pessoa da Silva', Cezar Luz Leitão Guerra², Otacílio de Oliveira Maia Júnior³, Roberto Lorens Marback ${ }^{4}$

\begin{abstract}
Choroidal folds is considered the most prevalent funduscopic finding in cases of orbital tumors. They are ripples in the retinal pigment epithelium, Bruch's membrane, the inner portion of the choriocapillaris and in some cases, may affect the neurosensory retina, and then called chorioretinal folds. Several ocular and systemic conditions are associated with the finding and must be properly investigated and, if necessary, promptly treated. In this review we discuss the general aspects of choroidal folds, emphasizing their characteristic features in the following ophthalmological imaging tests: Retinography, fundus autofluorescence, fluorescein angiography and optical coherence tomography.
\end{abstract}

Keywords: Choroid; Indocyanine green; Fluorescein angiography; Tomography; Optical coherence tomography; Retina

\section{RESUMO}

Dobras de coroide é considerado o achado fundoscópico mais prevalente nos casos de tumor orbitário. São ondulações no epitélio pigmentado da retina, membrana de Bruch, porção interna da coriocapilar e que, em alguns casos, podem acometer a retina neurossensorial, sendo então chamadas de dobras coriorretinianas. Diversas condições, oculares e sistêmicas, cursam com dobras de coroide e devem ser corretamente investigadas e, caso necessário, prontamente tratadas. Nesta revisão iremos abordar os aspectos gerais das dobras de coroide, enfatizando suas características nos seguintes exames de imagem: Retinografia, autofluorescência, angiofluoresceínografia e tomografia de coerência óptica.

Descritores: Coroide; Indocianina verde; Angiofluoresceinografia; Tomografia; Tomografia de coerência óptica; Retina

\footnotetext{
${ }^{1}$ Trainee at the Retina and Vitreous Unit of São Rafael Hospital, Monte Tabor Foundation, Salvador/BA, Brazil.

${ }^{2}$ Ophthalmologist, General Hospital of Salvador, Salvador/BA, Brazil.

${ }^{3}$ Retina and Vitreous Unit of São Rafael Hospital, Monte Tabor Foundation, Salvador/BA, Brazil.

${ }^{4}$ Professor at the Retina and Vitreous Unit of São Rafael Hospital, Monte Tabor Foundation, Salvador/BA, Brazil; in collaboration with the Ophthalmology Department of Professor Edgard Santos University Hospital, UFBA.
}

The authors declare no conflicts of interest

Received for publication: 15/6/2012 - Accepted for publication: 27/10/2012 


\section{INTRODUCTION}

$\mathbf{C}$ horoidal folds are grooves in the retinal pigment epithelium (RPE), Bruch's membrane, the inner portion of the choriocapillaris and, in some instances, the neurosensory retina, in which case they are called chorioretinal folds ${ }^{(1-3)}$

They were first described by Nettleship in 1884 as "peculiar choroidal lines" in a patient with papilledema secondary to an orbital mass lesion ${ }^{(1,4,5)}$.

\section{Clinical Aspects}

Clinically, the folds appear as linear images of alternating light and dark colour. The uppermost portion of a fold is called the peak and corresponds to the lighter region. The darker region corresponds to the depressed portion of the fold and is called the valley ${ }^{(4,5)}$. Initially they are thin and mild, similar to arrows or blood vessels ${ }^{(4)}$, and may be difficult to notice on ophthalmoscopy ${ }^{(1)}$. Over time they become larger and more pigmented, which

facilitates identification ${ }^{(1,4)}$.

Choroidal folds are not an unusual finding on fundus examination $^{(5)}$ and are the most prevalent finding in patients with orbital tumour ${ }^{(6)}$. They are usually asymptomatic but may cause visual disturbances such as hyperopia, astigmatism, and metamorphopsia ${ }^{(1,2,5)}$. Such symptoms are most evident in patients with recent folds of sudden onset ${ }^{(1,2)}$.
Patients with folds caused by intraconal orbital tumours typically have hyperopia, while astigmatism is more common in those with extraconal tumours ${ }^{(6)}$.

\section{Histopathogy}

Histopathological examination of choroidal folds shows grooves in the inner choriocapillaris, Bruch's membrane, and RPE. The RPE has normal features in the peaks and signs of thickening in the valleys. A study based on histopathology reported that vascular engorgement, haemorrhage, inflammation and compression of adjacent scleral tissue were the most common causes of thickening of the choroid in patients with choroidal folds ${ }^{(7)}$.

\section{Ophthalmic examination and imaging}

During ophthalmic examination, the best way to visualise choroidal folds is through biomicroscopy using a lens to examine the fundus, positioning the slit in an area adjacent to the one under study (the retroillumination technique) ${ }^{(1,10)}$. Using the slit perpendicular to the orientation of the folds and a green light filter also facilitates visualisation ${ }^{(4)}$. Retinal folds are the main differential diagnosis and are usually caused by epiretinal membrane ${ }^{(1,4)}$.

Ophthalmic imaging tests are helpful and present characteristic findings. Colour retinography, especially with a green filter, highlights the folds and is of great value in detecting and monitoring the condition (Figure $1 \mathrm{~A}-\mathrm{D})^{(4,9)}$.

Fluorescein angiography (FA) typically shows alternating hyper- and hypofluorescent lines, which are visible from the early stages and disappear in later stages without impregnation or

Table 1

Conditions that can cause choroidal folds.

\begin{tabular}{|c|c|}
\hline \multicolumn{2}{|r|}{ Ocular Causes } \\
\hline $\begin{array}{l}\text { Papilloedema } \\
\text { Acquired hiperopya }^{(1,3,5-5,7,8,8,15)} \\
\text { Congenita }^{(5,7)} \\
\text { Retinal detachment }^{(4,7,8)} \\
\text { Hypotonia }^{(1-5,7-9,17)} \\
\text { Post-traumatic }^{(1,4,7,8)} \\
\text { Choroidal tumour }^{(1,4,5,7,8,17)} \\
\text { Scleritis }^{(1,4,5,7,7,17)} \\
\text { Uvetis }^{(4,7,8,22)} \\
\text { Choroiditis }^{(4,5,7,22)} \\
\text { Papillitis }{ }^{(4,7,8)} \\
\text { Choroidal neovascularisation }\end{array}$ & $\begin{array}{l}\text { Choroidal detachment }{ }^{(4,7,8)} \\
\text { Uveal effusion syndrome }^{(7)} \\
\text { Venous occlusion }^{(7)} \\
\text { Posterior pole staphyloma }^{(1)} \\
\text { Central serous retinopathy }^{(4,5,8)} \\
\text { Microphthalmia }^{(4)} \\
\text { Optic disc drusen }{ }^{(4)} \\
\text { Angioid streaks }{ }^{(4,8)} \\
\text { Optic neuritis }{ }^{(1,2,4)} \\
\text { Chorioretinal scar }{ }^{(8)} \\
\text { After surgery for retinal detachment by scleral introflexion }{ }^{(1,4,5,7,9}\end{array}$ \\
\hline \multicolumn{2}{|r|}{ Orbital causes } \\
\hline $\begin{array}{l}\text { Thyroid ophthalmopathy }{ }^{(4,7,8)} \\
\text { Orbital tumour }(1,2,4,5,7-9,17) \\
\text { Mucocele }^{(8,18-20)}\end{array}$ & $\begin{array}{l}\text { Orbital inflammatory pseudotumour }{ }^{(1,5,7-9)} \\
\text { Orbital cellulitis }{ }^{(1,4,5,7-9)} \\
\text { Postoperative orbital oedema }\end{array}$ \\
\hline \multicolumn{2}{|r|}{ Other causes } \\
\hline $\begin{array}{l}\text { Sinusitis }^{(1,4,7,8)} \\
\text { Carotid-cavernous fistula }^{(4,7)} \\
\text { Increased intracranial pressure }^{(1,3-5,8,9)}\end{array}$ & $\begin{array}{l}\text { Drug-induced } \\
\text { Parasellar tumour }{ }^{(7,17)} \\
\text { Long-term space travel }\end{array}$ \\
\hline
\end{tabular}


Table 2

Correlation between the pattern of orientation of choroidal folds and possible diagnosis ${ }^{(1,4)}$

\begin{tabular}{ll}
\hline Padrão de orientação das dobras & Possível causa \\
\hline Radial from the optic nerve (NO) & Intraconal tomour \\
Concentric with the convex side toward the optic nerve & Extraconal tumour \\
Linear, temporal to the optic nerve & Hypotonia \\
Radial, with the centre in any portion of the retina & Choroidal neovascularisation \\
\hline
\end{tabular}

leakage. Hyperfluorescent lines correspond to peaks and hypofluorescent lines correspond to valleys (Figure $1 \mathrm{E}$ and F). ${ }^{(2,8,11)}$

Autofluorescence (AF) also shows a characteristic pattern. Alternating hyper- and hypofluorescent lines can be seen, however they are inverted in relation to FA. The hyperfluorescent lines in FA correspond to the hypofluorescent in AF and viceversa. This is because of the higher concentrations of RPE cells in valleys, resulting in larger amount of lipofuscin. AF is inferior to FA in showing choroidal folds, but it has the advantage of being a non-invasive test (Figure $1 \mathrm{G}$ and $\mathrm{H}$ ). ${ }^{(3)}$

The pattern shown in indocyanine green angiography (IGV) is not as characteristic as AGF and may display a smaller number of hyper- and hypofluorescent lines or a similar number of larger lines. The pattern may also change depending on the cause of choroidal folds. IGV is a useful method for studying the choroidal vascular structure and therefore plays an important role in the differential diagnosis and management of choroidal folds. ${ }^{(12)}$

Ultrasound imaging is very helpful in determining the cause of choroidal folds, and findings can vary depending on the aetiology. The most common findings include increased subarachnoid space, flattened posterior pole, and increased thickness of the retina and choroid layer ${ }^{(4,5,13)}$.

In optical coherence tomography (OCT), folds in the hyperreflective line formed by the inner portion of the choriocapillaris, Bruch's membrane, and RPE are easily identified. In some cases the neurosensory retina remains flat over these folds, while in others it is folded (chorioretinal folds) in a pattern similar to the underlying choroid (Figure 2A and B). In a case series with 8 patients a typical pattern of vitreous attachment was noted in patients with chorioretinal folds. There was vitreous detachment in regions corresponding to valleys, while it remained positioned normally in the apical portions of the folds. ${ }^{(2)}$

Pituitary tumour associated with hydrocephalus causing increased intracranial pressure is described in the literature and is an uncommon condition. ${ }^{(14)}$ Computed tomography and magnetic resonance imaging of the brain and orbits are essential to determine the presence of mass lesions and/or signs of intracranial hypertension. These tests can show signs such as a flattened posterior pole and an enlarged optic nerve sheath. ${ }^{(9,12,15)}$ The enlarged optic nerve sheath at its distal portion is believed to be the cause of the flattened posterior pole. ${ }^{(16)}$

\section{Finail considerations}

Choroidal folds tend to disappear after their cause is treated successfully, but the time until total remission is quite variable and may last from a few months to a few years, and they may become permanent in some cases. In a study on choroidal folds due to orbital tumours approximately $82 \%$ of patients still had choroidal folds three months after successful treatment.

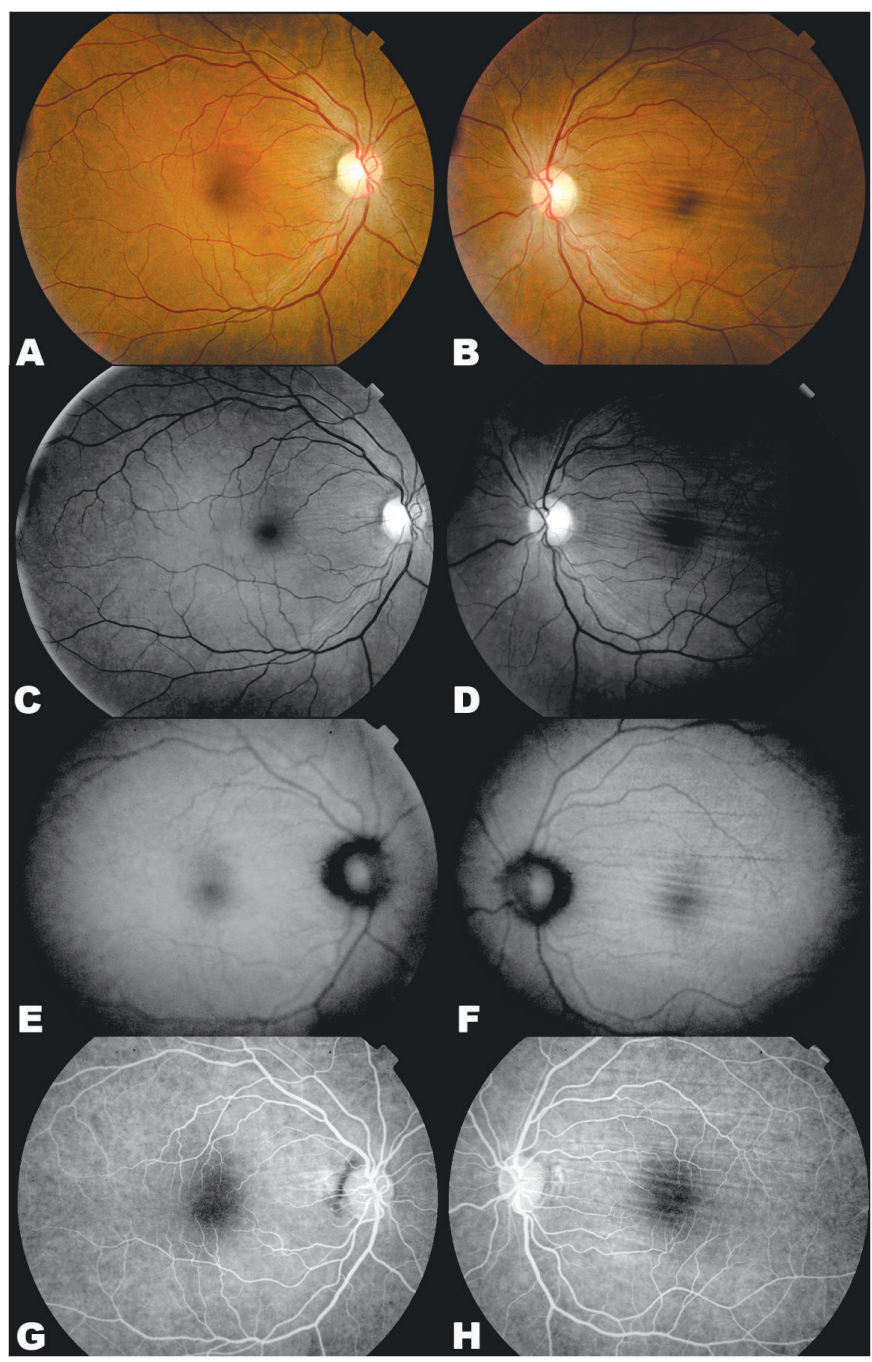

Figure 1: Images of a 51-year-old female with bilateral choroidal folds secondary to frontal mucocele. A and B: Simple retinography. C and D: Retinography with a green light filter. E and F: Autofluorescence. G and H: Fluorescein angiography.

\section{RefERENCES}

1. Mango CW, Sarraf D, Schwartz SD. Choroidal folds. In: Holz FG, Spaide RF, editors. Essentials in ophthalmology: medical retina. Berlin: Springer-Verlag; 2005. p. 65-75. 

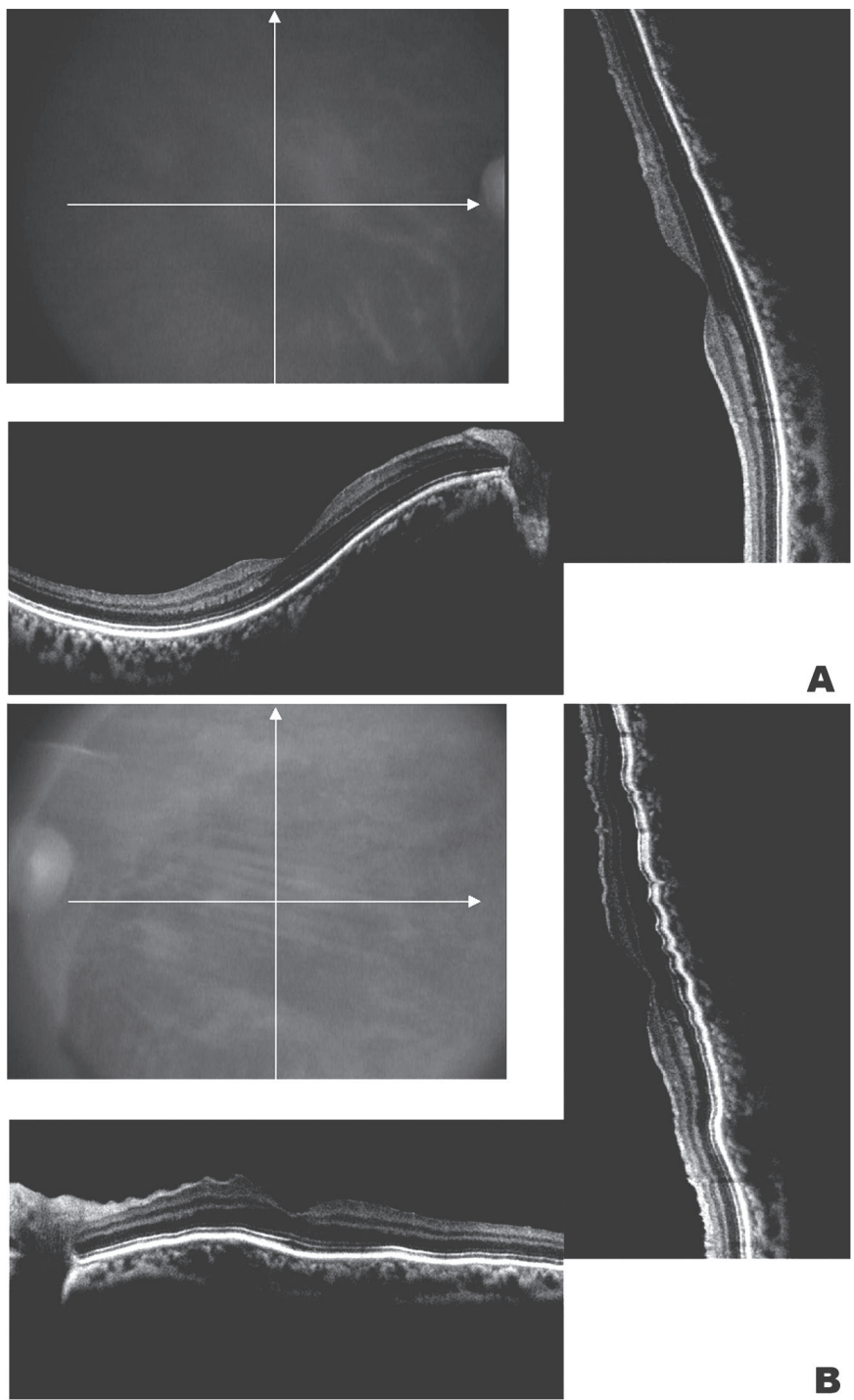

Figure 2: Optical coherence tomography of both eyes of the same patient. Perpendicular cuts through the centre of the fovea in an orientation similar to fundus examination. Figure A shows the right eye and Figure B shows the left eye

2. Giuffrè G, Distefano MG. Optical coherence tomography of chorioretinal and choroidal folds. Acta Ophthalmol Scand. 2007;85(3):333-6.

3. Fine HF, Cunningham ET, Kim E, Theodore Smith R, Chang S. Autofluorescence imaging findings in long-standing chorioretinal folds. Retin Cases Brief Rep. 2009;3(2):137-9.

4. Jaworski A, Wolffsohn JS, Napper GA. Aetiology and management of choroidal folds. Clin Exp Optom. 1999;82(5):169-76.
5. Lavinsky J, Lavinsky D, Lavinsky F, Frutuoso A. Acquired choroidal folds: a sign of idiopathic intracranial hypertension. Graefes Arch Clin Exp Ophthalmol. 2007;245(6):883-8.

6. Singh D, Pushker N, Bajaj MS, Saxena R, Sharma S, Ghose S. Visual function alterations in orbital tumors and factors predicting visual outcome after surgery. Eye (Lond). 2011;26(3):448-53.

7. Gree WR. The uveal tract. In: Spencer WH, editor. Ophthalmic pathology: an atlas and textbook. 4th ed. Philadelphia: WB Saunders 1996. p. $2110-5$

8. Kashiwada S, Ferrucci S, Peschke K, Grimes AL. Idiopathic choroidal folds. Clin Refract Optom. 2004;15:298-302

9. Murdoch D, Merriman M. Acquired hyperopia with choroidal folds Clin Experiment Ophthalmol. 2002;30(4):292-4.

10. Newell FW. Fundus changes in persistent and recurrent choroida folds. Br J Ophthalmol. 1984;68(1):32-5.

11. Norton EW. A characteristic fluorescein angiographic pattern in choroidal folds. Proc R Soc Med.1969;62(2):119-28

12. Haruyama M, Yuzawa M, Kawamura A, Yamazaki C, Matsumoto Y. Indocyanine green angiographic findings of chorioretinal folds. Jpn J Ophthalmol. 2001;45(3):293-300.

13. Atta HR, Byrne SF. The findings of standardized echography for choroidal folds. Arch Ophthalmol. 1988;106(9):1234-41.

14. Iglesias P, Macho LP, Díez JJ. Resolution of macroprolactinomainduced symptomatic hydrocephalus following cabergoline therapy. Age Ageing. 2004;33(4):410-2

15. Paz-Moreno J, Jiménez-Parras R. [Choroidal folds. A presentation of two cases]. Arch Soc Esp Oftalmol. 2010;85(1):38-40. Spanish.

16. Jacobson DM. Intracranial hypertension and the syndrome of acquired hyperopia with choroidal folds. J Neuroophthalmol. 1995;15(3):178-85

17. Taban M, Kosmorsky GS, Singh AD, Sears JE. Choroidal folds secondary to parasellar meningioma. Eye (Lond). 2007;21(1):147-50

18. Yap SK, Aung T, Yap EY. Frontal sinus mucoceles causing proptosis-two case reports. Ann Acad Med Singapore. 1998;27(5):744-7.

19. Tan CS, Yong VK, Yip LW, Amrith S. An unusual presentation of a giant frontal sinus mucocele manifesting with a subcutaneous forehead mass. Ann Acad Med Singapore. 2005;34(5):397-8.

20. Allen LE, Chisholm IH. Unusual funduscopic manifestations of an ethmoidal mucocele. Br J Ophthalmol. 1994;78(12):946-7.

21. Mader TH, Gibson CR, Pass AF, Kramer LA, Lee AG, Fogarty J, Tarver WJ, Dervay JP, Hamilton DR, Sargsyan A, Phillips JL, Tran D, Lipsky W, Choi J, Stern C, Kuyumjian R, Polk JD. Optic disc edema, globe flattening, choroidal folds, and hyperopic shifts observed in astronauts after long-duration space flight. Ophthalmology. 2011;118(10):2058-69. Comment in: Berdahl J, Fleischman $D$, Allingham RR, Fautsch $M$. Disc swelling and space flight. $O p h-$ thalmology. 2012;119(6):1290; author reply 1291.

22. Zhao C, Zhang M, Wen X, Dong F, Han B, Du H. Choroidal folds in acute Vogt-Koyanagi-Harada disease. Ocul Immunol Inflamm. $2009 ; 17(4): 282-8$

\section{Corresponding author:}

Ricardo Luz Leitão Guerra.

Rua Catarina Paraguaçu, 08, Graça. Salvador/BA, Brazil.

CEP: 40150-200

Tel/Fax: +557135256555 Cell phone: +5571 88228813

E-mail: ricardo@leitaoguerra.com.br 